\title{
Importance of Sports Journalism Education
}

\author{
Güven Büyükbaykal \\ Istanbul University, Istanbul, Turkey
}

\begin{abstract}
Today in every sphere of life, the concept of sport has great importance and demonstrates itself. The developments pertaining to different sports branches, particularly football, are conveyed to large masses by means of the mass media. The media monitors the sports world accordingly by means of the journalists specialized in this area. At this point, in order to enable the due coverage of various sports branches in the media and their being held in a more scientific and qualitative way, it is very important to provide and sustain specialization in sports journalism. Based on the fact that sport contributes a great deal to the physical and spiritual development of societies, the purpose of this study is to highlight the importance of the education to be provided in this area through different perspectives.

Keywords: sport, sports journalism, education
\end{abstract}

\section{Introduction}

Starting from its coming into view until today, the fact of sports has transformed to a trading area by showing various changes with its importance and profitability felt by everyone. Sports has transformed to the state of a big industry with its advertisement incomes, sponsorships, live broadcasts, club products devoted to the fans, club's stock exchange securities, sport materials sold in the stores, match ticket fees paid by the audiences setting their hearts on the club, combines cards and even with the 'special credit cards of the banks for the fans' and it has come off from its amateur spirit and transformed to a professionalized phenomenon.

At the present time, an important reason for the sports to become popular is also most of the youngsters who saw that sports yields money and what is more, great amounts of money; choose the sports not only for pleasure but also, as a profession. Again, by hoping the road going to success, believing in luck, they imagine to become rich. Because, there are millions of youngsters on one side who have the purpose of making big monies by becoming a star sportsman and there are millions of youngsters on the other side who dream about making money from the games of chance related with sports.

Mass media has assumed a big function for the sports to come into prominence and they have become the driving power to have the sports reach large masses of people. Together with works devoted to fast and technological progress encountered in the field of communication, a development related to sports taking place in any place of the world can be transmitted all around the world. With the extensive usage of different communication instruments; distribution and transfer of the information related to sports has gained acceleration. However, printed media has a different position in the eyes of the reader by always reflecting the news in the direction of its specific publishing understanding and making the topics or news in hand colorful and understandable with the using of photograph item.

Güven Büyükbaykal, Associate Professor, Journalism Department, Faculty of Communication, Istanbul University. 


\section{Definition of Sport and its General Characteristics}

Beyond physical training and leisure time concepts, sports is a form of the work interpreting the life through games. Within its general integrity, sport has developed with the aid of many different scientific disciplines and there is the possibility to define it by being based on its basic features. "With the shortest cut of wording, it means game, distraction, entertainment and getting away from the work... Additionally, sport is the occupation combining game with the racing, rewarding the winners as they have more physical capabilities, entailing continuous and intensive effort as it requires top level game, challenge and heavy muscle works" (Fişek, 1985, pp. 5-8).

At the present time, it is also possible to have the sports concept in hand with different forms by having various standpoints on it with accelerated scientific studies: "In our world giving ground to daily developing political rivaling, technical changes, social fluctuations, universal languages that can be perceived by everyone are considerably rare. Sport is one of them" (Bourg, 1992, p. 59).

In sports, basic purpose is to win. This ideal is pursued sometimes in the form of team and sometimes individually. "Sport games mean the success for the targets by using body technology under the pressure of time and opponent" (Yaman, 2003).

The struggle in these games is sometimes done at the level of countries and sometimes it takes place with the personal competition. However, it must never be done by going beyond the rules of gentlemanship in order to win. Because, gentlemanship and friendship underlie in all of the sports games. If these concepts are harmed, then the entire meaning and purpose of sports shall become dirty.

"It is possible to take the fact of sports until the known history of the humankind and it attracts the attention of the masses especially during the last two centuries with ever-increasing rate" (Sert, 2000, p. 14).

There are many factors coming in the forefront in this: Having the sports, and especially the branches like football and basketball, take place with priority in the government policies of the countries, having mass media give wide place to sports in ever-increasing way with every passing day, acceptance of the sports by the people from every age as an inevitable reality for a healthy living, having sport-economy relation offer a great potential and the impacts brought by sports-politics relation are known as the basic reasons.

\footnotetext{
Nowadays, sport is started to be done in the direction of multiple purposes. Sports done with the purpose of recreation is now done in the direction of many purposes such as healthy living, relaxation, to be able to work in the business life with more planned and programmed way, to decide instantaneously, consistency of the decisions given, improving defense and attack strategies. (Kaya, 2000, p. 246)
}

Sports provide contribution in gathering the people from different continent of the world having different ethnical, religious and cultural roots and it helps to bind them together. Live broadcastings of sports games all over the world from televisions cause millions and even billions of people share the same excitement at the same moment. Sports competitions can also help to eliminate the international disagreements between the countries: Table tennis game played between USA-China, competition of USA-Iran national football teams in 1998 World Cup, joint application of Turkey and Greece for the nomination in 2008 European Football Championship, Friendship game played in the Olympic Stadium in Istanbul between Galatasaray and Olimpiakos can be given as the examples.

If there is the need to take the topic in hand from another view point "Sport is the way of struggle of a person sustained with moral and physical activities first given against himself, then to nature, time and human. 
Sports can also provide a healthy, disciplined character to the person by giving respect for the rules and to be able to establish relationships in the society with love and understanding" (Ünlütepe, 1991, p. 61). In Turkey, very few young people choose sports as an amateur occupation or as a professional vocation. Many difficulties such as inadequate sport salons, insufficient incentives of the State, limited support of the public are the most important reasons why we cannot bring up sportsmen. If we overcome these kinds of issues, sports shall also progress in our country and it shall be able to reach the level deserved by it.

\section{Situation of Sports Journalism in Turkey}

At the present time, there are different sports branches representing Turkey with success in the international organizations with the licensed sportsmen and sportswomen continuing the activities, however; they also assume many issues together with them and want to be put into words in the public opinion. "However, sports press has limited itself with football. Without a doubt, there are reasons taking place for this circumstance such as having football as the most popular sports branch not only in Turkey but also in the entire world, having the successful teams in Turkish Football League in Istanbul just like the head office of the press and having the impact of the fans on the daily circulation, readers request for the football news and after all collection of football news is more economic" (Kaya, 2002, p. 166).

Football writership in Turkey has shown a progress in the form of being the fan of a team. At the present time, especially the three big ones of Istanbul; Fenerbahçe, Galatasaray and Beşiktaş are the teams taking place in the agenda with the news, articles, commentaries, estimations, praising and criticisms lengthiest way. The other teams of Turkish Football League are only mentioned when they have a success or when they become the subject of an event.

Heading, visual items such as photograph have started to occupy place more than the news text that forms the most important section of the news. It is possible to explain this situation of the printed sports press as providing advantage in the competition environment conducted by it with the mass media by applying the methods such as shortening the contents in order to gain mass of readers who do not have enough time at the stage of reading and focusing the attentions on magazine reporting understanding and giving more place to the items which have visual picturesqueness in football. In fact, printed press is able to immortalize with photographs for its readers how a goal is scored. Whereas, in live broadcasting or in the highlights of a match goal is viewed for few times and it passes by. It is able to attract the attention of the reader also with exciteful, interesting headings.

Again, the persons writing the news and commentaries of football in the printed sports press are generally former football players and for this reason they do not remain neutral and they always praise or criticize their teams. Despite of the fact that the persons doing commentaries related to football are the former football players, they scrutinize the matches in technical sense and they do superficial evaluations bereft of basis. Wordy warfare between newspapers' sports services or sports writers are personalized.

Football players who played football for long years and stopped playing football after having their jubilees are immediately employed by a newspaper as the sports writers. These persons, who do not carry the qualifications to be the football or sports writer, can be Beşiktaş, Galatasaray and Fenerbahçe writers. However, without getting into technical analysis of the game played, these writers cannot give anything else but they only transfer to readers of what they saw in the game and in the result of this, they reduce the quality of printed sports press each passing day. It is an undeniable reality that writers like this who only narrate the pass given 
and the scored goal are bringing our printed sports press down to a weak state day by day. Most of the writers who write substantial sports texts by having extreme quality either with their strong languages or in terms of the content they have in their articles are persons who did not play football formerly and this has the characteristic to prove what is said.

Together with the former football players, there are also writers who did not play football, however only following a special team by being the sympathizer of it. Of course, partisanship of these writers is at the bearable level when compared with the other segment. Because, when needed, these names exhibit more scientific and more concrete approaches to the criticisms they do and at the same time they also do constructive criticisms. Again, in the last period, writers such as Uğur Meleke, Tanıl Bora, Mehmet Demirkol and Altan Tanrikulu are able to place their articles on cause and effect relations not because they played football in the past but because they can follow industrial football in global arena and because of frequently following many other sports as well.

Because of having vocational discipline not connected to fundamental principles and traditions, it gives big damages to vocational association of sports writers. Having the famous football players owners of the corner in the sports pages right after their jubilees and after leaving the football field is generated from having vocational discipline not connected to determined rules. Extreme increase in football player origin writer staff is rapidly melting own sources of sports writership, in other words, blocks young sports writer candidates who had vocational training. When concession is also made to willing persons to become writers among the leading names in different vocation groups, sports writership was almost transformed to a hobby vocation.

In general terms, the issue of making false news seen in the press has also reflected in printed sports press at the present time. Ungrounded transfer news especially during summer months or in the half times of the leagues with the purpose of creating sensation is the best samples of this. Worthless, unqualified articles written with the purpose of arousing interest have taken the place of logical, technical and scientific articles.

Whereas, sports press must adopt the principle to reflect the sports to its readers with the expression language to encourage friendship, brotherhood, peace, sportsmanship and competition medium suitable with the rules instead of the articles having fanaticism in the forefront with the purpose of obtaining circulation, having dominance upon the reader, directing the reader. However, a sports press to catch a certain standard and to determine the publishing policy in the direction of the basic principles shall reach to success and shall be viewed by the readers with liking.

\section{Vocational Qualifications Required to Be in the Sports Journalist}

Sports pages of the newspapers are taking the lead among the sections attracting most of the attention of the current readers. It is an accepted reality that the newspapers are generally read by starting from their back pages. Messages carried in the commentaries, news and even the photographs in the sports pages are able to have influence on public masses and they direct sports public opinion within short period.

Like in the journalists assuming duties in different areas, sports journalist must primarily have social responsibility. First step of a journalist's social responsibilities is to forward news to its readers. In addition, the sports journalist must not ignore compliance with the reality when he informs the society with his news. He must not give wrong and missing information. In order to fulfill this responsibility completely, sports journalist must be the person who handles every subject with sensitively by having broad sports culture and renewing himself continuously, following the sports agenda as well as vocational training. A journalist does not create 
the events by himself, he transfer the happenings to public by taking the events in hand within the framework of certain principles. Sports journalists must reveal the issues either in the agenda of sports or in the area of sports press and he must be able to discuss the same. He must be neutral and independent; he must put the realities in the forefront but not his thoughts.

On the other hand, "In order to be able to transfer the observed events, developments and news to the readers correctly and in understandable way, written expression ability of a journalist must be developed, he must use dictation and punctuation in a good way and at the same time he must know the technical terms related with the topic. News must be written with a language having plain expression that can be understood by everybody as well as the content of the news and time, having the existence of the articles having literal beauty in the newspaper are among the expectations of the readers. Since sports pages of the newspapers are also one of the leading sections of the school-age young generation, the language used by the media can also be seen as an important indirect element of the education" (Özsoy \& Doğu, 2006, p. 132).

One of the points needed to pay most attention by the printed sports press is complying with the rules of grammar. It is seen that verbs, names and objects are used in the wrong places in sports pages. Street language is used instead of sentences having rule, attention is not paid to writing of conjunctions. In using of the street language, desire of the journalist to reach his reader with the shortest way is the primary factor. In the result of this approach, errors come in sight in terms of writing rules. Since the basic purpose is to sell more, such errors are done. For example, separately written -de, -da, -ki and interrogative particle -mı ve -mi's are written adjacent. Since the sports writers cannot find the word, they evoke the impression that their vocabularies are insufficient. A word is used a few times consecutively in the same sentence or paragraph. On the other hand, it is leaped to the eye that some sports writers do not search the original of the word and they even do not use the spelling book and dictionary. On the other hand, insistently using of the words having Turkish equivalent with their forms in the foreign language constitutes another distress. For example, the sentence of "gave support to offense" is persistently written in the place of "gave support to the attack". In fact, the word of "offense" in French is used in the meanings of insult or sin against the God.

In conclusion, printed sports press is valid in the articles related to each sports branch and at the same time, it has to pay attention to grammar rules also in the news and articles related to football. Writing-expression language in compliance with the rules also becomes an indicator for the respect to the readers. Using the words correctly and in their right places shall give an end to ambiguity as well. Instead of wrongly used football terms, current correct equivalents of them must be used as approved by International Football Association Board (IFAB) which is renewed almost every year, as well as the ones indicated in International Football Association Federations (FIFA). Again, each sports writer must have the habit to use the spelling book and dictionary. In place of the articles having the fanaticism idea in the forefront with the purpose of obtaining circulation, having dominance on the readers and directing them, sports press must adopt the principle to reflect the sports to its readers with the expression language to encourage friendship, brotherhood, peace, sportsmanship and competition medium suitable with the rules.

It is required to transfer sportive developments without changing and as they are, they must not be distorted and exaggeration must be avoided. To give an example to this, as the news particularly related to 3 big teams have dominance in the sports pages, untrue transfer news are transferred to the readers from time to time. It is the condition to follow the sports press in the foreign countries, to have the command of a foreign language to be able to provide news and comments by establishing contacts with the news sources taking place inland 
and abroad. Additionally, a sports journalist must be the person who knows principles and methods of the sports and who likes sports by adopting fair play philosophy in the sports. Also having the knowledge of law and regulation pertaining to sports provides great benefit for the sports journalist in transferring a subject to his readers in details and apprehensively when a development takes place.

\section{Importance of Vocational Education in Sports Journalism}

Especially in the leadership of TSYD, vocational training courses, seminars or certificate programs must be arranged with the collaborative works of the press establishments and related departments of Communication Faculties. Again, press establishments must bring sports writers, experts, trainers and technicians from the leading sport clubs, sport schools and printed press organs of the world and they must contribute to development of young sports journalism candidates in the subject of the novelties becoming evident in the world and for the practices connected to this. In order to have the reflection of different points of view, to write up quality articles, review essays satisfying the readers in terms of information in the sports pages, it is required to cause the sports journalism candidates gain researchers spirit.

There must be training seminars arranged within the institution in order to be able to use rapidly developing communication technologies and to be able to use this technology in the vocational area efficiently and fast. Again, in the scope of these trainings, archive awareness and top-level sports history knowledge must be provided for the sports journalist. This kind of furnishing gives the possibility to establish connection with the past and comparison when sport events are transferred to the readers and at the same time, it shall bring the advantage in making commentaries. For example, when a sports journalist has detailed information about the previous performance of the athlete while watching the competition of an athletics, for example while writing the news about the record breaking event on the track, it shall be very useful to give the information to the readers about the athlete who had that record previously as well as providing the time and the place of the same information.

Additionally, in the scope of vocational training, required information must also be provided about national and international sports organizations: "To have the knowledge about the structures, operations, organs, committees, boards as well as the directors of the national organizations such as General Directorate of Youth and Sports, Sports Federations and international institutions such as International Olympic Committee (UOK), International Football Federation (FIFA), European Football Federation (UEFA), International Basketball Federation (FIBA), International Wrestling Federation (FILA) are among the information to take place in the repertoire of the journalist while writing the news" (Özsoy \& Doğu, 2006, pp. 138-139).

In order to have the success by a sports journalist, he must have expertise in at least one sports branch. "Today, many of our people believe that they know better than the technical director of the team in the topic of which player must play, in which system the team must play. For this reason, sports journalists must have deep knowledge about the sports branch they shall narrate to their readers... There is a definite specialization in European countries and between the sport journalists in USA. The ones who are not the expert of that branch cannot do any work in that branch. For example, expert of every branch assumes the duty related with his/her branch in the Olympics. Even olympizm has its specialist. In Turkey, other than football, there are limited number of specialists only in basketball, athletics and wrestling... In the sports media of our country, which is currently called as 'football media' as well, 'sports club specialization' is understood in place of 'sports branch specialization' when specialization is mentioned” (Özsoy \& Doğu, 2006, p. 139). 
If evaluation is done in the scope of the universities in Turkey, it is seen that the number of lessons related to sports communication, its operating, economy and law as well as the number of related program is scarcely any. For the sake of giving sample model, Kadir Has University Sports Law Research and Application Center is giving education with the name of "Sports Communication Certificate Program" on the point of meeting the existing deficit. In this program, it is aimed to assume the educations to bring up well-educated sports directors and sports communicators and correspondents who think about working.

In the scope of the program, there are sports history, printed sports press, international sports press, reporting ethics, comparative reporting perspectives, sports culture and tribune folklore, sports sociology, olympizm and Olympics history, editorship, page layout, photo reporting, archiving, looking at the sports in newspaper managements, live competition narration, public relations, going public by Turkish Clubs, sports economy, club economies, international organizings, dilemmas and practice of sports law lessons read. Again, in another example, in Istanbul University Faculty of Communication, there is sports press lesson given at license level and the lessons named as sports industry and interaction between the sports press are given at doctorate level and it is aimed to complete the academic fulfillments of the young candidates who want to become sports journalist.

\section{Conclusion}

As is in different areas of journalism, specialization also in the field of sports has big importance in terms of having reliability of the news as well as its acceptance and gaining attention, validity, to have it taken into consideration and to follow it. The news written up by a journalist who is the expert of his subject always arouses more interest. Specialization in this area is also important in terms of the institutional identity, prestige of the press institution where journalist works as well as the contention of the same institution with the competitors in the sector.

Education focused activities obtained by the journalists on the basis of school during the education years on the path of specialization or throughout the process for the ones who stepped in the vocational life shows itself also in the areas of sports journalism. Also in many universities of abroad, there are educations continues in the area of sports journalism and specialist sports journalists are brought up in this direction. It is especially observed in the sports pages of the daily newspapers and in the daily sports newspapers published in the western countries that sports correspondents are specialized in different sports branches. On the other hand, in Turkey, specialization has inadequate level other than football.

In order to specializing at this point, in order to be able to employ successful, qualified sports journalist of the subject, there is the requirement to have close cooperation of Press Institutions with the Faculties of Communication and Sport Vocational High Schools or Sport Sciences Faculties. Continuity and characteristic of vocational education is important in order to adopt the principle to reflect the sports to its readers with the expression language to encourage friendship, brotherhood, peace, sportsmanship and competition medium suitable with the rules instead of the articles having fanaticism in the forefront with the purpose of obtaining circulation, having dominance upon the reader, directing the reader.

Particularly, attention must be focused on practical applications and theoretical content in the scope of sports press taking place in the existing specialist journalism lesson taking place in Communication Faculties' Journalism Departments. Support must be provided by the Faculties to students who want to become sports journalists in future so that they can have their external trainings in the sports services of different press 
institutions and this way they can gain experience and to enable to see the technicality of the vocation. With the seminars and conferences to be arranged, it shall be useful to have the meeting of the leading names of the sports world and the segment having interest for the topic. Turkish Sports Writers Association must also be the pioneer with the vocational seminars and courses to be arranged by it in order to eliminate the deficiencies in the sense of education for sports journalists actively working and to have timely practice of the occurring technologic novelties.

\section{References}

Bourg, J. F. (1992). Spor ve Televizyon: Etik Rekabet İle Ekonomik Düzen Arasında (Sports and Television: Between ethical rivalry and economic order). Medya Dünyas1, Derleyen: Jean-MarieCharon, Çeviren: OyaTatlıpınar, İstanbul, İletişim Yayınları.

Fişek, K. (1985). 100 Soruda Türkiye Spor Tarihi (Turkish history of sports in 100 questions). İstanbul, Gerçek Yayınevi.

Kaya, A. Y. (2000). Spor Basınının Kamusal Boyut ve İslevleri (Public dimensions and functions of sports press). İ.Ü. İletişim Fakültesi Dergisi, Sayı: X, İstanbul, İ.Ü.Basımevi.

Kaya, A. Y. (2002). Dünya'da ve Türkiye'de Basının Gelişimi İle Türk Basınında Sporun Haber Öğeleri Açısından İncelenmesi (Analysis of sport in Turkish printed media regarding news elements through the development of press in the world and in Turkey). Selçuk Üniversitesi İletişim Fakültesi Dergisi, Cilt: 2, Sayı: 3, Konya.

Özsoy, S., \& Doğu, G. (2006). Spor Gazeteciliğinin Bugünkü Durumu ve Mesleki Nitelikleri (Sports journalism today and professional qualifications). İstanbul Üniversitesi İletişim Fakültesi Dergisi, Sayı: 25, İstanbul, İ.Ü. Basım ve Yayınevi Müdürlüğü.

Sert, M. (2000). Gol Atan Galip (Who Scores a Goal, Wins). İstanbul, Bağlam Yayınc1lık.

Ünlütepe, M. Ş. (1991). Türkiye'de Spor Gazeteciliği ve Tarihsel Gelişimi (Sports journalism in Turkey and its historical development). Yayımlanmamış Yüksek Lisans Tezi, İ.Ü.S.B.E., İstanbul.

Yaman, H. (2003). Gelecekte de futbol olacak mi? (Will there be football in the future?). Retrieved from http://www.ntvmsnbc.com 